\title{
Procedure for Handling 4-H Accounts: Rights and Responsibilities ${ }^{1}$
}

Marilyn Norman and Joy C. Jordan ${ }^{2}$

\section{Rights and Responsibilities of 4-H Units for Fiscal Management}

Chartered units are authorized to use the 4- $\mathrm{H}$ Name and Emblem for 4-H educational or informational uses. Thus, they are encouraged to plan and implement educational programs and community service projects in their community.

Units have the authority to receive private money to support the operating expenses of the 4- $\mathrm{H}$ Youth Development Program. All funds for these purposes, regardless of the source, should be managed and accounted for accurately. 4- $\mathrm{H}$ unit members and leaders are responsible for all resources (money, equipment, property, etc.) raised, collected, or otherwise obtained and expended in the name of 4-H. These resources belong to the University of Florida and are not owned by any individual. Again, this responsibility is delegated under the authority of the County Extension Director.

The unit may receive funds by virtue of its own fund-raising enterprises or from other sources, such as gifts or bequests from individuals, organizations, or businesses. The treasurer has the responsibility for recording, disbursing, depositing, and properly accounting and classifying the unit funds. 4-H funds should never be commingled with other funds, such as private, business, or other institutional funds.
Budget management is a primary responsibility of 4-H unit officers. If there are deviations from the planned budget, the officers are obligated to inform the members to be sure that there is full agreement and support or approval of any changes. Officers have the responsibility to inform both the unit leader and the Extension faculty if concerns continue to exist.

\section{Accounting Procedures for 4-H Units}

\section{Books and Financial Records}

Most banks today use automated deposit techniques that result in a computer-generated deposit receipt. Those receipts must be kept to document the deposit and verify bank statements. If the bank is not yet automated, bank deposits should be noted in the appropriate passbook for each account, dated and initialed by the teller.

\section{Checkbook}

The most common type of checkbook is one which has a stub or register for noting the number, date, amount, and item or purpose for which the check is drawn, as well as a place for noting deposits. This helps identify the check with the bill paid. The original bill is kept in the treasurer's files as evidence in support of payment. The canceled check or copy of the check (as provided by the

\footnotetext{
1 This document is $4 \mathrm{H}$ 5.3, one of a series of the Florida 4-H Program, Florida Cooperative Extension Service, Institute of Food and Agricultural Sciences, University of Florida. Published February 2007. Please visit the 4-H Website at http://4h.ifas.ufl.edu/Curriculum/index.htm.

2

Marilyn Norman, Associate Professor in the Department of Family, Youth and Community Sciences and State 4-H Program Leader, and Joy C. Jordan, Associate Professor in the Department of Family, Youth and Community Sciences, Institute of Food and Agricultural Sciences, University of Florida, Gainesville, 32611.
} 
banking institution), properly inscribed, can serve as a receipt. One alternative checkbook used today is the one-write check system, which records the information as the check is written. Cost per check is usually higher, but this system ensures that all important information is captured.

\section{Ledgers}

Ledgers provide separate entries for receipts and disbursements. Entries are made in the calendar order in which they occur. Pages are divided into columns, each titled with the descriptive heading appropriate to the items listed under income and disbursements. Additional headings for funds should be established as appropriate in order to separately account for funds from different sources and expenses by different category or for different purposes. Units using the 4-H Treasurer's Book meet these requirements.

\section{Bank Statements}

These are a record of deposits, withdrawals, fees paid, and interest earned on a monthly basis. The balance shown on each statement should be reconciled with the unit's balance monthly. Treasurers should note any discrepancies and check on them with the bank within one week of receiving the statement.

\section{Other Necessary and Supporting Records}

These include bills, receipts, canceled checks, written authorizations for disbursements not covered in the approved budget, and minutes of meetings approving budget changes or special nonbudgeted items.

The use of personal computers and associated computerized accounting and financial reportgenerating programs by $4-\mathrm{H}$ treasurers is encouraged.

\section{Cashiering}

Cashiering is the management, use, and accounting of all cash activities. These are some guidelines to follow when dealing with cash.

- Volunteers may accept currency, checks, money orders, cashier checks, etc. for 4-H administration, programs, events, and activities. Checks should be made out to the particular 4-H club or affiliate and not to any individual. Checks and money orders should be restrictively endorsed to the applicable organization immediately upon receipt.

- Each 4-H club or unit should have its own account, with an individual account number and precoded deposit slips.

- Individual accountability for cash must be maintained throughout all cashiering operations (e.g., do not pay bills from incoming cash).

- A cash receipt (prenumbered receipts are preferred) must be issued for each individual collection of cash. All cash receipts should be accounted for.

- In some cases, it may not be practical to issue a cash receipt. In these cases, collection of funds should be documented by a Statement of Cash Collections, to be filled out daily. The statement should indicate who collected the money, total funds collected (attach cash register tape), and the name of the banking institution where funds will be deposited. After the funds are deposited, the deposit receipt should be attached to the Statement of Cash Collections.

- Statements of Cash Collections must be signed by two individuals, one of whom must be an adult who is unrelated to the other signer. The receipts should be turned over to the treasurer for the bank deposit.

- To ensure the safe handling of currency and to protect the individuals (youth or adult) handling the cash, where practical, funds should be deposited daily or turned over each day to the treasurer to deposit.

- Treasurers are required to make deposits of funds received within one week and are encouraged to make daily deposits. If, under certain circumstances, deposits cannot be made daily or turned over every day to the treasurer, the funds should be receipted daily and kept in a secure place overnight.

- On rare occasions, a petty cash fund may be needed for miscellaneous items. However, the

February 2007 
use of petty cash is not encouraged and should not be used as a substitute for sound planning and budgeting. Petty cash should be reconciled, at a minimum, on a monthly basis. In petty cash allotments, the cash plus the cash receipts for expenditures should equal the initial authorized amount. All petty cash allotments should be entered in the general ledger as petty cash, along with the person's name to whom the small amount of cash is issued.

- If 4-H funds are stolen, the theft must be reported to the nearest police office immediately. A copy of the police report should be given to the Extension office and the County Extension Director as soon as it is available. 